\section{Irrigating Based on Daily Water Use Reduces Nursery Runoff Volume and Nutrient Load Without Reducing Growth of Four Conifers}

\author{
Nicholas A. Pershey and Bert M. Cregg \\ Department of Horticulture, Michigan State University, East Lansing, MI 48824
}

Jeffrey A. Andresen

Department of Geography, Michigan State University, East Lansing, MI 48824

R. Thomas Fernandez ${ }^{1}$

Department of Horticulture, Michigan State University, East Lansing, MI 48824

Additional index words. evapotranspiration, nitrates, phosphates, water management, water quality, container production

\begin{abstract}
The objectives of this study were to quantify irrigation volume, runoff volume and nutrient content, and plant growth of container-grown conifers when irrigated based on plant daily water use (DWU) vs. a standard irrigation rate. Four conifer taxa were grown in 10.2-L (no. 3) containers subjected to four irrigation treatments from 23 June to 16 Oct. 2009 and 6 June to 31 Oct. 2010. The taxa were: 1) Chamaecyparis obtusa Sieb. \& Zucc. 'Filicoides', 2) Chamaecyparis pisifera (Sieb. \& Zucc.) Endl. 'Sungold', 3) Thuja occidentalis L. 'Holmstrup', and 4) Thuja plicata D. Donn 'Zebrina'. The four irrigation treatments were: 1) control application of $\left.19 \mathrm{~mm} \cdot \mathrm{d}^{-1}, 2\right)$ irrigation applied to replace $100 \%$ DWU (100 DWU) per day, 3) applications alternating $100 \%$ with $75 \%$ DWU in a 2-day cycle (100-75 DWU), and 4) a 3-day application cycle replacing $100 \%$ DWU the first day and 75\% DWU on the second and third days (100-75-75 DWU). Irrigation treatments did not affect plant growth index $\left\{G I=\left[\left(H+W_{N S}+W_{E W}\right) / 3\right]\right\}$ in 2009. In 2010, GI of $C$. obtusa 'Filicoides' was greater for $100 \mathrm{DWU}$ than the control plants. Seasonal total water applied for $100,100-75$, and $100-75-75$ DWU was $22 \%, 32 \%$, and $56 \%$ less, respectively, than the control amount of $117 \mathrm{~L}$ per container in 2009 (114 days) and $24 \%, 18 \%$, and $24 \%$ less than the control amount of $165 \mathrm{~L}$ per container in 2010 (147 days). Scheduling irrigation based on DWU reduced runoff volumes and (nitratenitrogen) $\mathrm{NO}_{3}{ }^{-}-\mathrm{N}$ and (phosphate-phosphorous) $\mathrm{PO}_{4}{ }^{3-}-\mathrm{P}$ load compared with the control. Irrigating based on DWU reduced water application and runoff volumes and $\mathrm{NO}_{3}{ }^{-}-\mathrm{N}$ and $\mathrm{PO}_{4}{ }^{3-}-\mathrm{P}$ load while producing plants of equal or greater size than control plants.
\end{abstract}

Producers must irrigate container-grown nursery plants frequently, often multiple times daily, because of container volume limitations and substrate properties. This increases water extraction demands and places nurseries in competition for water resources with population centers, industry, and other agricultural sectors (Beeson et al., 2004; O'Neill and Dobrowolski, 2011). Since 1992, annual water applications to container nursery stock

Received for publication 9 July 2015. Accepted for publication 10 Aug. 2015

This project was supported by the USDA National Institute of Food and Agriculture, hatch project number MICL02010.

We appreciate the financial support provided by Michigan State University Project GREEEN, Michigan Department of Agriculture Horticulture Fund, and the in-kind support of plants, substrate and fertilizer from Spring Meadow Nursery, Inc., Renewed Earth LLC, and Harrell's LLC. We also like to thank Aaron Warsaw, Glenn Jarrell, and Max Braun for their assistance on this project.

${ }^{1}$ Corresponding author. E-mail: fernan15@msu.edu.
2006). Using a similar irrigation system that monitored $\theta$ using time-domain reflectometry (TDR) sensors, Cornejo et al. (2005) improved irrigation application efficiency $22 \%$ compared with a timer-controlled irrigation system.

In addition to concerns about the quantity of water used, runoff leaving nurseries may contain $\mathrm{NO}_{3}{ }^{-}-\mathrm{N}$ and $\mathrm{PO}_{4}{ }^{3-}-\mathrm{P}$, among other contaminants, at concentrations as high as 8 and $5 \mathrm{mg} \cdot \mathrm{L}^{-1}$, respectively (Sharma and Bolques, 2007). Although those $\mathrm{NO}_{3}{ }^{-} \mathrm{N}$ levels do not exceed the U.S. environmental protection agency (EPA) safe drinking water threshold $\left(10 \mathrm{mg} \cdot \mathrm{L}^{-1}\right)$, the Michigan Department of Environmental Quality reported that where $\mathrm{NO}_{3}{ }^{-} \mathrm{N}$ is already present, just 0.3 $\mathrm{mg} \cdot \mathrm{L}^{-1}$ of $\mathrm{PO}_{4}{ }^{3-}-\mathrm{P}$ may promote cyanobacteria blooms that can damage sensitive ecosystems (Anonymous, 2008). In addition to regulating concentration, total maximum daily load (TMDL) standards have been developed on a case-specific basis to set a maximum rate at which nutrients can enter a water body (EPA, 2011). The total average annual 10-year loads of $\mathrm{N}$ and $\mathrm{P}$ entering the Chesapeake Bay are 1.6 and 1.5 times higher than the 187 and 18 million pound caps for $\mathrm{N}$ and $\mathrm{P}$ (CBF, 2010). As a result, since 2002, the state of Maryland requires agricultural operations to draft management plans for $\mathrm{N}$ and P (Lea-Cox et al., 2001). In Florida, agriculture accounts for $98 \%$ of all $\mathrm{P}$ imports into the Lake Okeechobee watershed, where a P TMDL of $40 \mu \mathrm{g} \cdot \mathrm{L}^{-1}$ places agricultural nonpoint sources under intense pressure (FDEP, 2001). Nutrient TMDLs have been implemented in Michigan for P levels in 12 watersheds, although few nurseries are affected in this instance (Anonymous, 2011). Research has shown decreased nutrient loading with DWU-based irrigation management. Warsaw et al. (2009b) found total quantities of $\mathrm{NO}_{3}{ }^{-} \mathrm{N}$ in runoff reduced by $38 \%$ and $59 \%$ in $100 \%$ and $75 \%$ DWU applications compared with their control.

The objectives of this project were to study the effects of four DWU-based irrigation treatments on plant performance and runoff water volume and quality. Plant GI and dry weight, DWU, runoff water volume and $\mathrm{NO}_{3}{ }^{-}-\mathrm{N}$ and $\mathrm{PO}_{4}{ }^{3-}-\mathrm{P}$ concentrations and loads were determined to compare the irrigation treatments.

\section{Materials and Methods}

Site description. The Michigan State University Horticulture Teaching and Research Center (HTRC), Holt, MI, is located at lat. $42.67^{\circ} \mathrm{N}$, long. $-84.48^{\circ} \mathrm{W}$, and elevation of $264 \mathrm{~m}$. Plants were grown on $3 \times 6 \mathrm{~m}$ nursery production beds covered with 6-mm impermeable high density polyethylene plastic and overlain by polypropylene woven permeable landscape fabric. The beds were oriented east to west along the long axis, sloped to the center and westward, and channeled runoff water into a collection basin positioned below grade on the west end of each bed. Rectangular basin frames were made of wood 
and spanned the width of the production beds. An impermeable 30-mm ethylene propylene diene monomer pond liner was affixed to each frame (see Warsaw et al., 2012 for schematic). Production beds were spaced $3.7 \mathrm{~m}$ apart to minimize irrigation drift from neighboring beds. A Michigan Enviro-weather station is located at the HTRC to monitor environmental conditions (MSU, 2011).

A 1.9 -cm-diameter $24-\mathrm{V}$ alternating current solenoid valve (various manufacturers) activated irrigation in each production bed. Six nozzles (U8 Series; Rain Bird Corporation, Azusa, CA) were mounted on $1.3-\mathrm{cm}$ diameter by $0.66-\mathrm{m}$ high risers. The sprinklers were spaced $2.44 \mathrm{~m}$ apart along the long edge of each production bed with all water directed inward. Four $90^{\circ}$ nozzles were positioned on the corners of the production area, and one $180^{\circ}$ nozzle was positioned between the corner nozzles on each long axis per production area. Each nozzle provided a $2.44 \mathrm{~m}$ radius of throw for $100 \%$ nozzleto-nozzle overlap. Irrigation system distribution uniformity (DU) and output in each treatment replicate were tested in 2009 using 16 rain gauges randomly interspersed throughout the irrigation zone and allowed to collect water for $20 \mathrm{~min}$. The average application rate was $30.6 \mathrm{~mm} \cdot \mathrm{h}^{-1}$ with a DU of $69 \%$. Distribution uniformity and output in each treatment replicate were again tested in 2010 with an average application rate of 30 $\mathrm{mm} \cdot \mathrm{h}^{-1}$ and DU of $88 \%$. The improvement in DU occurred because the system operating pressure was increased in 2010.

Plant material. Rooted cuttings of C. obtusa Sieb. and Zucc. 'Filicoides', C. pisifera Sieb. and Zucc. 'Sungold', T. occidentalis L. 'Holmstrup', and T. plicata Donn 'Zebrina' in $5.7 \times 5.7 \mathrm{~cm}$ plug containers were obtained from a commercial nursery on 1 Aug. 2008. They were planted in 10.2-L containers with an 85 pine bark: 15 peatmoss $(\mathrm{v} / \mathrm{v})$ substrate between 2 and 9 Sept. 2008. All cultural practices except irrigation were identical for all treatments. On 19 May 2009, plants were spaced $45 \mathrm{~cm}$ on center on the production beds. On 22 June 2009 and 6 June 2010, 54 g of 19N$2.6 \mathrm{P}-10 \mathrm{~K}$ controlled-release fertilizer with micronutrients $(5-6$ month release at 26.7 or $21.1{ }^{\circ} \mathrm{C}$, Polyon ${ }^{\circledR}$ Reactive Layers Coating, Harrell's Inc., Lakeland, FL) was top dressed to each container. Weeds were removed by hand pulling as necessary. Plants were overwintered from 2009 to 2010 in a minimally heated $\left(-2.2{ }^{\circ} \mathrm{C}\right)$ quonset house covered with $4-\mathrm{mm}$ overwintering film permitting 30\% light transmission. After overwintering, plants were placed on the production beds in their original configuration on 11 May 2010.

Experimental design. Four irrigation treatments were replicated three times and randomly assigned to 12 production beds in a completely randomized design. The treatments were: 1) control application of $\left.19 \mathrm{~mm} \cdot \mathrm{d}^{-1}, 2\right)$ irrigation applied to replace $100 \%$ daily water use (100DWU), 3) applications alternating 100\% with $75 \%$ DWU in a 2 -d cycle (100-75 DWU), and 4) a 3-d application cycle replacing $100 \%$ DWU on the first day and $75 \%$ DWU on the

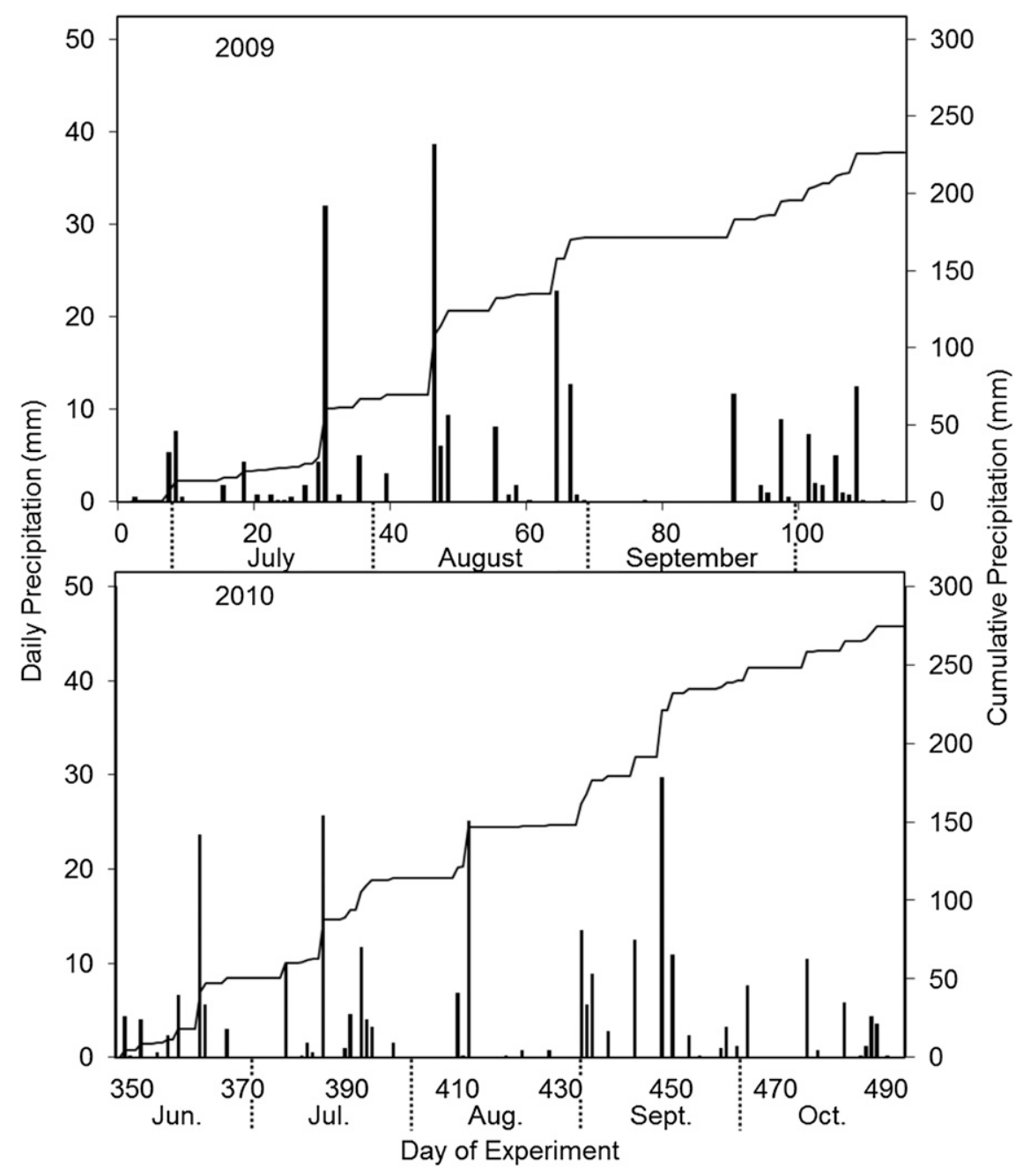

Fig. 1. Daily (bars) and cumulative (line) precipitation from 25 June to 16 Oct. (Day 114) 2009 and 7 June (Day 348) to 31 Oct. 2010 (Day 494). Data obtained from the Enviro-weather Automated Weather Station Network.

second and third days (100-75-75 DWU). A control irrigation rate of $19 \mathrm{~mm} \cdot \mathrm{d}^{-1}$ was chosen based on Fare et al. (1992) as a conventional nursery irrigation rate. Each treatment replicate contained six subreplicates of each of the four species for a total of 24 experimental plants in each production bed. Experimental plants were randomized in three rows of eight at the center of the production bed. Guard plants surrounded the perimeter of each replicate to reduce edge effects and consisted of several species having similar growth rates to the experimental plants. Guard plants were arranged in the same sequence in each treatment replicate in both years. Irrigation treatments were applied every day from 23 June 2009 to 16 Oct. 2009 (treatment duration $=114 \mathrm{~d}$ ) and 7 June 2010 to 31 Oct. 2010 (treatment duration $=147 \mathrm{~d}$ ). In both seasons, DWU irrigation applications were always made based on the species with the highest DWU within each treatment. In the cool months between growing seasons, all plants were uniformly irrigated to container capacity via an overhead system as necessary.

$D W U$ and irrigation scheduling. Substrate volumetric water content $(\theta)$ was measured in 2009 for every plant using a TDR soil moisture sensor (ThetaProbe Type ML2x; Delta-T Devices Ltd., Cambridge, UK) connected to a handheld reader (ThetaMeter Hand-Held Readout Unit Type HH1; Delta-T Devices Ltd.). At initiation of the study, irrigation was applied until the substrate for all plants exceeded container capacity. Gravimetric water was allowed to drain for $30 \mathrm{~min}$. Then an initial $\theta$ measurement was taken for each plant, and a final measurement was taken after $24 \mathrm{~h}$. For each container, the Thetaprobe was inserted vertically into the substrate to a depth of $6 \mathrm{~cm}$ in three locations $120^{\circ}$ apart halfway between the center and the outer wall of the container. The measurements were converted to $\theta$ using a substrate-specific equation developed by Warsaw et al. (2009a) for the same substrate. The $\theta$ differential was multiplied by the average container substrate volume $(9.7 \mathrm{~L} /$ container) to determine DWU and the application rate of the irrigation system to determine irrigation rate. Control and DWU-based treatments were programmed into a time-based controller (Rain Bird ESP-12LX Plus; Rain Bird Corporation, Azusa, CA) for the period until the next measurement of DWU. Irrigation began at $0700 \mathrm{HR}$ daily. New DWU were obtained about every $21 \mathrm{~d}$. 


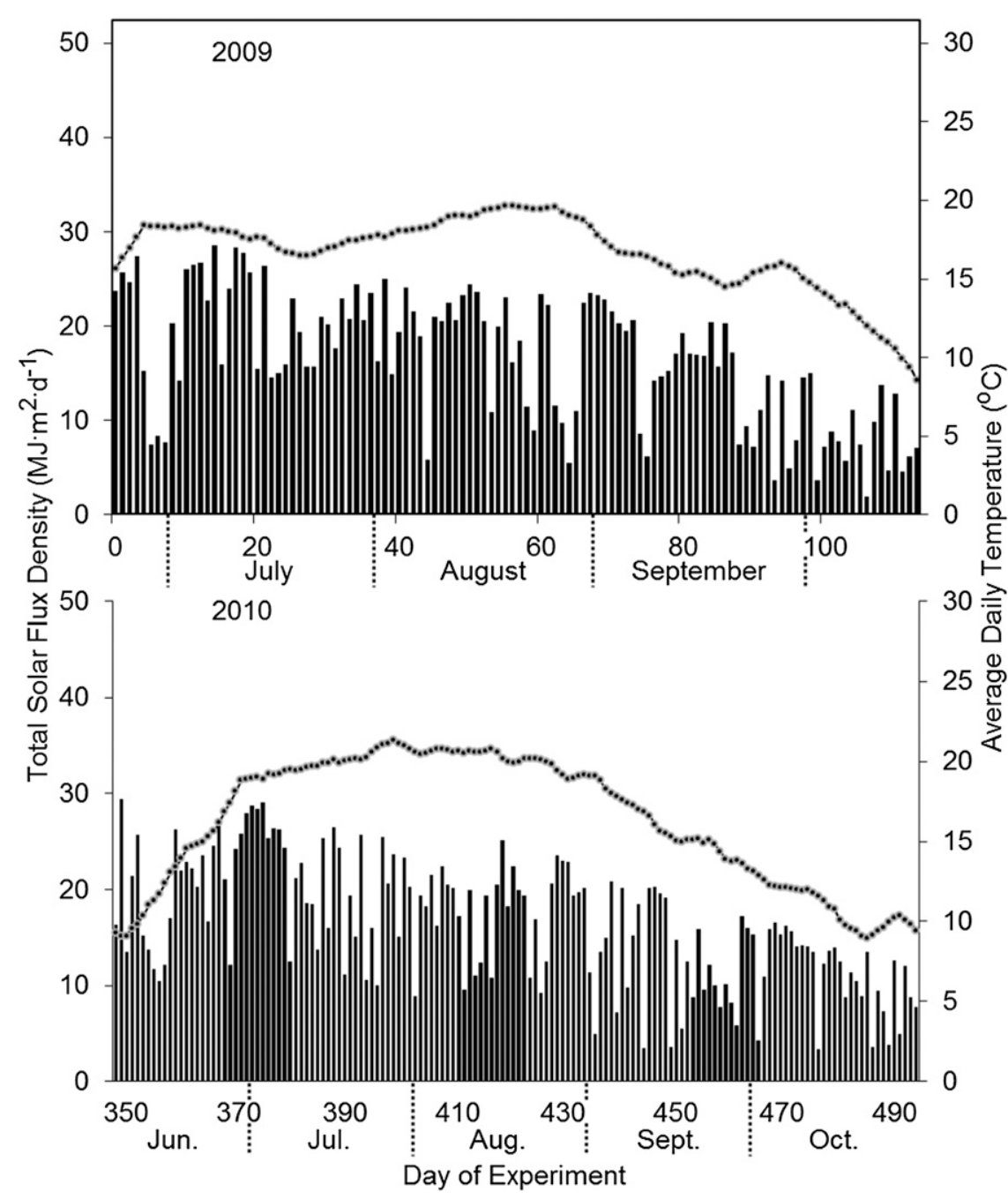

Fig. 2. Daily total solar flux density (bars) and daily average temperature (line) from 25 June to 16 Oct. (Day 114) 2009 and 7 June (Day 348) to 31 Oct. 2010 (Day 494). Data obtained from the Enviroweather Automated Weather Station Network.

Table 1. Total irrigation applied (L per container) to four irrigation treatments from 25 June to 16 Oct. 2009 (113 d) and 7 June to 31 Oct. 2010 (146 d).

\begin{tabular}{lc}
\hline Treatment & $\begin{array}{c}\text { Total irrigation applied } \\
(L \text { per container })\end{array}$ \\
\hline Control $^{\mathrm{z}}$ & 2009 \\
100 DWU & $116.96 \mathrm{a}^{\mathrm{y}}$ \\
$100-75$ DWU & $91.29 \mathrm{~b}$ \\
$100-75-75$ DWU & $79.46 \mathrm{c}$ \\
& $75.81 \mathrm{~d}$ \\
Control & 2010 \\
100 DWU & $157.29 \mathrm{a}$ \\
$100-75$ DWU & $124.89 \mathrm{a}$ \\
$100-75-75$ DWU & $135.11 \mathrm{a}$ \\
\hline
\end{tabular}

${ }^{\mathrm{z}}$ Control $=19 \mathrm{~mm}$ per application; $100 \mathrm{DWU}=100 \%$ daily water use (DWU) replacement each day; 100 75 DWU $=2$-d cycle alternating $100 \%$ and $75 \%$ DWU; and 100-75-75 DWU = 3-d cycle 100\% DWU replacement the 1 st day then $2 \mathrm{~d} 75 \%$ DWU replacement. Irrigation scheduling based on: 2009) highest DWU of the four taxa recorded on each day of sampling; 2010) highest DWU of the four taxa in each treatment replicate each day.

y Means separation performed with Tukey's test ( $\alpha=$ $0.05), \mathrm{n}=115 \mathrm{~d}$ (2009), and $\mathrm{n}=147 \mathrm{~d}$ (2010). Means followed by the same letter(s) are not different.
Irrigation was applied to bring the substrate to container capacity, and each container was weighed after drainage ceased using an electric balance (model PM 30; Mettler-Toledo, Inc., Columbus, $\mathrm{OH}$ ). Five subsequent weights were taken over a 24-h dry-down period and time was recorded to correlate with sensor measurements. Calibrations were developed using the PROC REG function in SAS (SAS Institute, Cary, NC) before inclusion in the micrologger program using version 2.7.0.16 of CRBasic Editor (Campbell Scientific, Inc., 2006).

Each day from 7 June to 31 Oct., DWU was calculated as:

$$
\mathrm{DWU}=\theta_{\text {initial }}-\theta_{\text {final }}
$$

where $\theta_{\text {initial }}=\theta 1 \mathrm{~h}$ after irrigation and $\theta_{\text {final }}=\theta$ immediately before next irrigation cycle. The micrologger program began the irrigation cycle each day at $0700 \mathrm{HR}$. On 7 June, with no $\theta_{\text {initial }}$ to reference from previous days, substrate moisture had to be brought to container capacity before recording the initial $\theta$. From 2000 HR on 5 June to 0600 HR on 6 June, $31.23 \mathrm{~mm}$ of steady rainfall occurred, which added $1.75 \mathrm{~L}$ to each container. This was sufficient to bring the substrate to container capacity for $\theta_{\text {initial }}$ on Day 1 of the experiment. The program determined the highest DWU in the treatment replicate, which was then multiplied by the irrigation system application rate to determine a run time in seconds. The appropriate treatment fraction of $100 \%$ or $75 \%$ was then multiplied by the run time before activating the relay controller for the necessary duration.

Plant performance. Crop coefficients $\left(\mathrm{K}_{\mathrm{c}}\right)$ were determined for each taxon receiving 100 DWU (well-watered and no limitations on crop growth or evapotranspiration) using the formula, $\mathrm{K}_{\mathrm{c}}=\mathrm{ET}_{\mathrm{A}} / \mathrm{ET}_{0}$ (Allen et al., 1998), where $\mathrm{ET}_{\mathrm{A}}$ is actual crop evapotranspiration (measured as DWU) and $\mathrm{ET}_{0}$ is reference evapotranspiration obtained from the on-site weather station (www.enviroweather. msu.edu). An adjusted $K_{c}\left(K_{c \text { adj }}\right)$ was determined using the same equation but with plants under potentially growth and/or ET limiting conditions (Allen et al., 1998). The weather station calculates $\mathrm{ET}_{0}$ using the modified Penman equation (Kincaid and Heerman, 1974). Plants were classified using $K_{c}$ or $K_{c}$ adj as low $(<2)$, moderate $\left(2 \leq \mathrm{K}_{\mathrm{c}}\right.$ or $\left.\mathrm{K}_{\mathrm{c} \text { adj }}<3\right)$, or heavy $(\geq 3)$ water users as described by Warsaw et al. (2009a).

Monthly GI was calculated as the average of plant height $(\mathrm{H})$ from the container rim to the highest point of the plant and plant widths along the north-south $\left(\mathrm{W}_{\mathrm{NS}}\right)$ and the eastwest axis $\left(\mathrm{W}_{\mathrm{EW}}\right)\left[\mathrm{GI}=\left(\mathrm{H}+\mathrm{W}_{\mathrm{NS}}+\mathrm{W}_{\mathrm{EW}}\right) / 3\right]$. Growth index increase (GII) was calculated as the difference between the final GI for each season minus the first GI measured in 2009 (for 2009 season, $\mathrm{GII}=\mathrm{GI}_{\text {final2009 }}-\mathrm{GI}_{\text {initial2009; }}$; for 2010, GII $=\mathrm{GI}_{\text {final2010 }}-\mathrm{GI}_{\text {initial2009). }}$ A permanently affixed container label was used to maintain orientation of the plants. For C. obtusa 'Filicoides', plant shoot dry weight was measured using three plants taken from each treatment replicate. The stem was cut at 
the substrate surface, and the entire top was bagged, oven dried, and weighed.

Runoff collection and analysis. Runoff water from the production beds was collected for two consecutive days each month. Runoff collection basins were completely emptied and cleaned before each irrigation event after which runoff was sampled. Runoff collection occurred first on $1 \mathrm{~d}$ when treatments received $100 \%$ DWU followed by another day when $75 \%$ DWU was applied to applicable treatments. Water was allowed to drain off the production beds for $0.5 \mathrm{~h}$ after irrigation. A small pump and vacuum were used to transfer water from the collection basin into a container to measure volume of total runoff recovered. Water samples were obtained from each treatment replicate to measure

Table 2. Seasonal daily water use (DWU) (L per container per day) of four conifers grown in 10.2-L containers under four irrigation treatments administered 25 June -16 Oct. 2009 and 7 June -31 Oct. 2010 .

\begin{tabular}{lllll}
\hline & \multicolumn{4}{c}{ Seasonal DWU } \\
\cline { 2 - 5 } Taxa & Control $^{\mathrm{z}}$ & $100 \mathrm{DWU}$ & $100-75 \mathrm{DWU}$ & $100-75-75 \mathrm{DWU}$ \\
\hline 2009 & & & & \\
Chamaecyparis obtusa 'Filicoides' & $0.644 \mathrm{Ba}^{\mathrm{y}}$ & $0.749 \mathrm{ABa}$ & $0.702 \mathrm{ABa}$ & $0.849 \mathrm{Aa}$ \\
$\quad$ Chamaecyparis pisifera 'Sungold' & $0.776 \mathrm{ABa}$ & $0.763 \mathrm{ABa}$ & $0.700 \mathrm{Ba}$ & $0.859 \mathrm{Aa}$ \\
Thuja occidentalis 'Holmstrup' & $0.763 \mathrm{Aa}$ & $0.726 \mathrm{Aa}$ & $0.784 \mathrm{Aa}$ & $0.836 \mathrm{Aa}$ \\
Thuja plicata 'Zebrina' & $0.675 \mathrm{Ba}$ & $0.670 \mathrm{Ba}$ & $0.680 \mathrm{Ba}$ & $0.889 \mathrm{Aa}$ \\
2010 & & & & $0.643 \mathrm{Aa}$ \\
C. obtusa 'Filicoides' & $0.619 \mathrm{Aa}$ & $0.507 \mathrm{Bc}$ & $0.675 \mathrm{Aa}$ & $0.420 \mathrm{Cb}$ \\
C. pisifera 'Sungold' & $0.596 \mathrm{Ba}$ & $0.704 \mathrm{Aa}$ & $0.689 \mathrm{Aa}$ & $0.622 \mathrm{Aa}$ \\
T. occidentalis 'Holmstrup' & $0.533 \mathrm{Ba}$ & $0.381 \mathrm{Cd}$ & $0.561 \mathrm{ABb}$ & $0.490 \mathrm{Bb}$ \\
T. plicata 'Zebrina' & $0.393 \mathrm{Cb}$ & $0.589 \mathrm{Ab}$ & $0.380 \mathrm{Cc}$ & \\
\hline
\end{tabular}

${ }^{\mathrm{z}}$ Control $=19 \mathrm{~mm} \cdot$ per application $(1.07 \mathrm{~L}$ per day); $100 \mathrm{DWU}=100 \% \mathrm{DWU}$ replacement each day; 100 $75 \mathrm{DWU}=2$-d cycle alternating $100 \%$ and $75 \%$ DWU; and 100-75-75 DWU = 3-d cycle with 100\% DWU replacement the 1st day then $2 \mathrm{~d} 75 \%$ DWU replacement. Irrigation scheduling based on: 2009) highest DWU of the four taxa recorded on each day of sampling; 2010) highest DWU of the four taxa in each treatment replicate each day.

${ }^{y}$ Means separation performed with Tukey's test $(\alpha=0.05),(2009 n=18,2010 n=3)$. Comparison between means in each row is marked with capital letters. Comparisons between means in each column, within respective years, are indicated by lower case letters. Means followed by the same letter(s) are not different.

$\mathrm{NO}_{3}{ }^{-}-\mathrm{N}$ and $\mathrm{PO}_{4}{ }^{3-}-\mathrm{P}$ concentrations in runoff water. Samples were maintained at $3{ }^{\circ} \mathrm{C}$ until being submitted to the Michigan State University Soil Testing Laboratory for $\mathrm{NO}_{3}{ }^{-} \mathrm{N}$ and $\mathrm{PO}_{4}{ }^{3-}-\mathrm{P}$ analysis. The cadmium reduction method was used for $\mathrm{NO}_{3}{ }^{-}-\mathrm{N}$ analysis and the Bray and Kurtz P-1 Test for $\mathrm{PO}_{4}{ }^{3-}-\mathrm{P}$ analysis (Frank et al., 1998). To determine net nutrient load, bulk quantities of nutrients in the runoff were calculated by multiplying nutrient concentrations by the volume of runoff collected and are expressed as $\mathrm{g} \cdot \mathrm{ha}^{-1} \cdot \mathrm{d}^{-1}$. The proportion of $\mathrm{NO}_{3}{ }^{-}-\mathrm{N}$ and $\mathrm{PO}_{4}{ }^{3-}-\mathrm{P}$ recovered were calculated as the ratio of nutrient quantities recovered to the total $\mathrm{N}$ or $\mathrm{P}$ applied.

Statistical analysis. Data for each species were analyzed individually for irrigation vol-

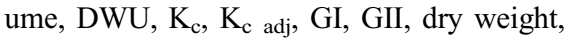
runoff recovery volume, nutrient concentration, nutrient load, and percent nutrient recovery. Data were found to be normal using the PROC UNIVARIATE procedure in SAS (SAS Version 9.1; SAS Institute, Cary, NC). Data tested with ANOVA using the PROC GLM procedure of SAS. When significant $(\alpha=0.05)$, Tukey's honestly significant test was used to separate means.

\section{Results and Discussion}

Irrigation volume. Cumulative and average daily $\mathrm{ET}_{0}$ for the 2009 treatment period

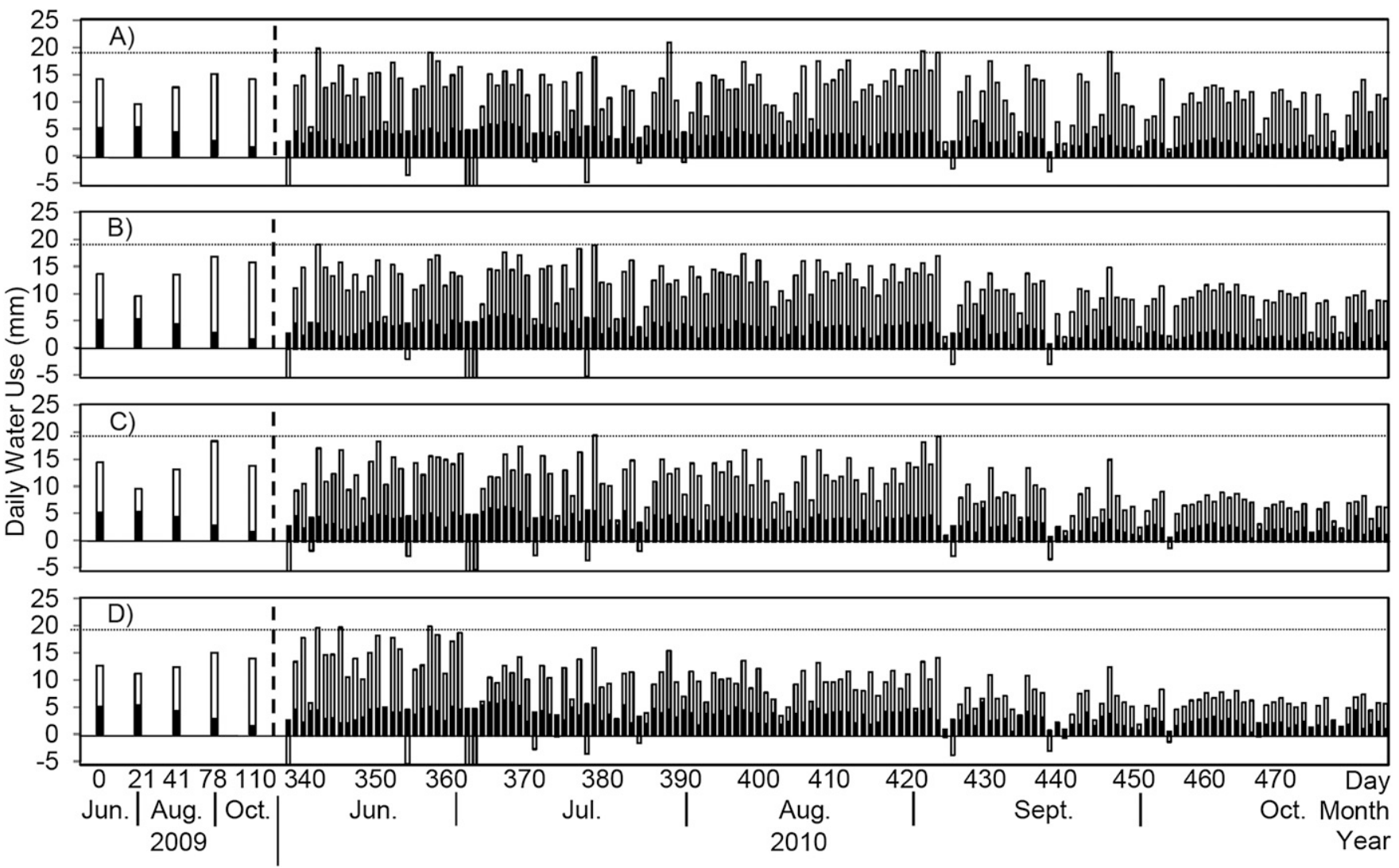

Fig. 3. Daily water use (DWU) from 25 June to 16 Oct. 2009 and 7 June to 31 Oct. 2010 of (A) Chamaecyparis obtusa 'Filicoides', (B) Chamaecyparis pisifera 'Sungold', (C) Thuja occidentalis 'Holmstrup', and (D) Thuja plicata 'Zebrina' grown in 10.2-L containers. The shaded portions of bars represent daily ET0 from 25 June to 16 Oct. 2009 and 7 June to 31 Oct. 2010. White portions of each bar represent DWU. Negative values indicate precipitation in excess of DWU. Dotted horizontal line indicates control treatment of $19 \mathrm{~mm}$ per application. Dashed vertical line separates 2009 and 2010 seasons. Daily ET0 values obtained from the Enviro-weather Automated Weather Station Network. 
equaled 369 and $3.15 \mathrm{~mm}$ and in 2010 were 491 and $3.34 \mathrm{~mm}$. A total of 226 and $275 \mathrm{~mm}$ of rainfall (Fig. 1) occurred during the 2009 and 2010 treatment periods contributing 13 and $16 \mathrm{~L}$ per container. Irrigation was not applied on $3 \mathrm{~d}$ when rainfall exceeded $19 \mathrm{~mm}$ in 2009 and $10 \mathrm{~d}$ in 2010. Temperature and solar flux were highest in July and August before declining fairly steadily from September until the end of data collection for each season (Fig. 2). Between the time the plants were moved outdoors on 11 May 2010 and the beginning of treatments on 7 June, $10 \mathrm{~mm}$ of irrigation was applied daily to all treatments. An additional $133 \mathrm{~mm}$ of precipitation occurred during this period for a total of $403 \mathrm{~mm}$ of water received by all treatments. During the treatment period, total irrigation applied to the control was $2166 \mathrm{~mm} \mathrm{(117} \mathrm{L/container;}$ Table 1) in 2009 and $2795 \mathrm{~mm} \mathrm{(157}$ $\mathrm{L} /$ container) in 2010. Compared with the control, daily irrigation applications to the 100, 100-75, and 100-75-75 DWU treatments were reduced by $22 \%, 32 \%$, and $35 \%$ in 2009 and $22 \%, 15 \%$, and $21 \%$ in 2010 , respectively (Table 1). Across each 2- or 3-d cycle, irrigation applications in the 100-75 and 100-75-75 DWU treatments were $87.5 \%$ and $83.33 \%$ of DWU.

There were no differences in seasonal DWU between taxa within irrigation treatments in 2009 (Table 2). Seasonal DWU in 2009 within taxa tended to be greatest for 100-75-75 DWU when differences occurred with few differences because of other treatments. All taxa had differences in seasonal DWU because of irrigation treatments, but there was no distinct pattern. When differences occurred between taxa within treatment in 2010, DWU of C. obtusa 'Filicoides' and $C$. pisifera 'Sungold' was typically highest and T. plicata 'Zebrina' was typically lowest with some exceptions.

As expected, daily fluctuations in DWU were similar to $\mathrm{ET}_{0}$ (Fig. 3). Maximum DWU in 2009 occurred on Day 78 (10 Sept.). The control application rate was higher than DWU for all days measured in 2009. In the first half of 2010, DWU was generally higher before declining in early September (Fig. 3), which corresponded to increasing frequency of precipitation (Fig. 1) and decreasing temperatures and solar flux (Fig. 2). The highest DWU recorded for any taxa in 2010 occurred for C. obtusa 'Filicoides' on Day 399 (28 July 2010). Moreover, DWU only exceeded the control irrigation rate on $4 \mathrm{~d}$ for $C$. obtusa 'Filicoides', 3 d for T. plicata 'Zebrina', $2 \mathrm{~d}$ for T. occidentalis 'Holmstrup', and $1 \mathrm{~d}$ for C. pisifera 'Sungold' (Fig. 3). Consequently, irrigation was applied to the control in excess of plant needs on the majority of days throughout this study, particularly later in the season as temperatures and solar flux fell and precipitation was frequent.

Based on Warsaw et al. (2009a), all taxa in 2009 were high water users and most were high users in $2010\left(\mathrm{~K}_{\mathrm{c}}\right.$ or $\mathrm{K}_{\mathrm{c} \text { adj }}>3$; Table 3). However, seasonal $\mathrm{K}_{\mathrm{c}}$ adj of $T$. plicata 'Zebrina' in 2010 was less than three for all but $100 \mathrm{DWU}\left(\mathrm{K}_{\mathrm{c}}=3.43\right)$ and $\mathrm{K}_{\mathrm{c}}$ was less
Table 3. Seasonal crop coefficients (L per container per day) calculated as DWU:ET 0 of four conifers grown in 10.2-L containers under four irrigation treatments administered 25 June-16 Oct. 2009 and 7 June-31 Oct. 2010.

\begin{tabular}{|c|c|c|c|c|}
\hline \multirow[b]{2}{*}{ Taxa } & \multicolumn{4}{|c|}{ Crop coefficient } \\
\hline & $\overline{\text { Control }^{z}}$ & $100 \mathrm{DWU}$ & $100-75 \mathrm{DWU}$ & $100-75-75 \mathrm{DWU}$ \\
\hline \multicolumn{5}{|l|}{2009} \\
\hline Chamaecyparis obtusa 'Filicoides' & $3.41 \mathrm{Ba}^{\mathrm{y}}$ & $4.46 \mathrm{ABa}$ & $4.16 \mathrm{ABa}$ & $5.36 \mathrm{Aa}$ \\
\hline Chamaecyparis pisifera 'Sungold' & $4.53 \mathrm{Aa}$ & $4.73 \mathrm{Aa}$ & $4.10 \mathrm{Aa}$ & $5.65 \mathrm{Aa}$ \\
\hline Thuja occidentalis 'Holmstrup' & $4.39 \mathrm{Aa}$ & $4.19 \mathrm{Aa}$ & 4.68 Aa & $5.32 \mathrm{Aa}$ \\
\hline Thuja plicata 'Zebrina' & $3.74 \mathrm{Ba}$ & $3.99 \mathrm{Ba}$ & $4.05 \mathrm{Ba}$ & $5.79 \mathrm{Aa}$ \\
\hline \multicolumn{5}{|l|}{2010} \\
\hline C. obtusa 'Filicoides' & $3.84 \mathrm{Aa}$ & $2.86 \mathrm{Bc}$ & 4.15 Aa & $3.95 \mathrm{Aa}$ \\
\hline C. pisifera 'Sungold' & $3.70 \mathrm{Aab}$ & $4.15 \mathrm{Aa}$ & 4.27 Aa & $2.46 \mathrm{Bb}$ \\
\hline T. occidentalis 'Holmstrup' & $3.20 \mathrm{Ab}$ & $2.11 \mathrm{Bd}$ & $3.31 \mathrm{Ab}$ & $3.57 \mathrm{Aa}$ \\
\hline T. plicata 'Zebrina' & $2.27 \mathrm{Cc}$ & $3.43 \mathrm{Ab}$ & $2.10 \mathrm{Cc}$ & $2.81 \mathrm{Bb}$ \\
\hline
\end{tabular}

${ }^{\mathrm{z}}$ Control $=19 \mathrm{~mm}$ per application (L per container per day); $100 \mathrm{DWU}=100 \%$ daily water use (DWU) replacement each day; 100-75 DWU $=2$-d cycle alternating $100 \%$ and $75 \%$ DWU; and $100-75-75$ DWU $=3$-d cycle $100 \%$ DWU replacement the 1 st day then $2 \mathrm{~d} 75 \%$ DWU replacement. Irrigation scheduling based on: 2009) highest DWU of the four taxa recorded on each day of sampling; 2010) highest DWU of the four taxa in each treatment replicate each day.

${ }^{y}$ Means separation performed with Tukey's test $(\alpha=0.05), \mathrm{n}=18$ (2009) and $\mathrm{n}=3$ (2010). Means followed by the same letters (capital letters in rows, lowercase letters in columns) are not different within respective years.

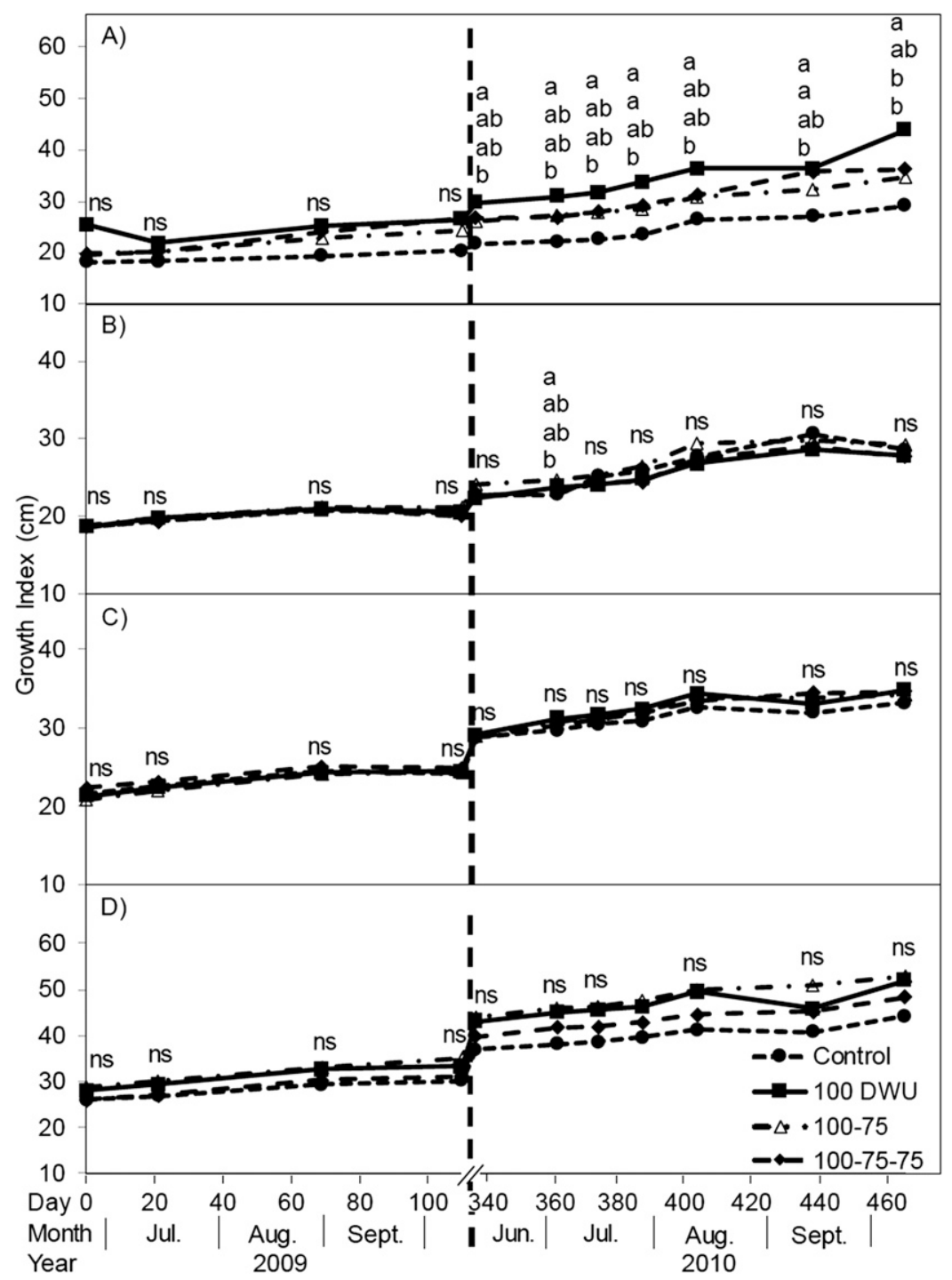

Fig. 4. Growth index of (A) Chamaecyparis obtusa 'Filicoides', (B) Chamaecyparis pisifera 'Sungold', (C) Thuja occidentalis 'Holmstrup', and (D) Thuja plicata 'Zebrina' grown in 10.2-L containers and subjected to four irrigation treatments from 25 June (Day 0) to 16 Oct. 2009 and 7 June (Day 348) to 31 Oct. 2010. Control $=19 \mathrm{~mm}$ per application; $100 \mathrm{DWU}=100 \%$ daily water use $(\mathrm{DWU})$ replacement each day; $100-75 \mathrm{DWU}=$ 2-d cycle alternating 100\% and 75\% DWU; and 100-75-75 DWU = 3-d cycle with 100\% DWU replacement the 1st day then $2 \mathrm{~d} 75 \%$ DWU replacement. Irrigation scheduling based on: 2009) highest DWU of the four taxa recorded on each day of sampling; 2010) highest DWU of the four taxa in each treatment replicate each day. Dashed vertical line separates 2009 and 2010 seasons. Each day was analyzed separately (Tukey's test, $\alpha=0.05$ ). Means followed by the same letters are not different. $\mathrm{NS}=$ not significant, $\mathrm{n}=18$. 
than three for C. obtusa 'Filicoides' and T. occidentalis 'Holmstrup' for 100 DWU, which classifies them as a moderate water users. Among all taxa, T. plicata 'Zebrina' had both the lowest $K_{c}$ adj at 2.1 in 2010 for 100-75 DWU and the highest at 5.8 for 100 75-75 DWU in 2009 (Table 3). Using the same classification methods as this study, T. plicata Donn 'Atrovirens' was rated a low user in Michigan in 2006 with a $\mathrm{K}_{\mathrm{c}}$ of 1.7 , and T. occidentalis L. 'Techny' grown in 2007 was rated a moderate user with a $\mathrm{K}_{\mathrm{c}}$ of 2.6 (Warsaw et al., 2009a). Overall $\mathrm{K}_{\mathrm{c}}$ in flowering shrubs reached as high as 6.8 (Warsaw et al., 2009a). Others reported maximum $\mathrm{K}_{\mathrm{c}}$ of 4.7 (Schuch and Burger, 1997) and 5.1 (Burger et al., 1987) for container-grown shrubs. Schuch and Burger (1997) presented an approach involving the reassessment of $\mathrm{K}_{\mathrm{c}}$ every few weeks. In addition, Niu et al. (2006) showed that $\mathrm{K}_{\mathrm{c}}$ differed by calendar month for containergrown shrubs in Texas. Such intervals are similar to those between DWU measurements made in 2009 from this study. Figure 3 also illustrates the day-to-day fluctuations in the $2010 \mathrm{~K}_{\mathrm{c}}$, expressed as DWU: $\mathrm{ET}_{0}$. Daily calculation of $\mathrm{K}_{\mathrm{c}}$ using sensors currently is not widely adopted by nurseries but advances in sensor technology (Chappell et al., 2013; Lea-Cox et al., 2013) and improved affordability (Belayneh et al., 2013) may make this feasible to some extent in the near future.

Plant growth. There was no effect of treatment on GI within taxa in 2009 (Fig. 4). In 2010, GI (Fig. 4) and GII (Table 4) for $C$. obtusa 'Filicoides' of 100 DWU were larger than the control plants on all sampling dates. During the treatment period, C. obtusa 'Filicoides' grew more than any taxa in the DWU treatments $(12.7,9.5$, and $9.3 \mathrm{~cm}$ for 100,100 75, and 100-75-75 DWU, respectively). Similar to GI, shoot dry weight of C. obtusa 'Filicoides' was $163.6 \mathrm{~g}$ for $100 \mathrm{DWU}$ and $134.9 \mathrm{~g}$ for $100-75-75 \mathrm{DWU}$, both higher than the control of $51.7 \mathrm{~g}$.

Several studies have shown that plants can be produced under water conserving irrigation regimes with minimal impact on growth. In a deficit irrigation study, $90 \%$ of shoot growth could still be produced at irrigation volumes of $1.0 \times$ available water compared with $1.5 \times$ available water, $\approx 40 \%$ less irrigation applied (Groves et al., 1998). Similarly, a low leaching fraction (LF) of 0.0 to 0.2 conserved $44 \%$ of irrigation water vs. a LF of 0.4 to 0.6 , although the $0.0 \mathrm{LF}$ resulted in an $8 \%$ reduction in total plant dry weight (Tyler et al., 1996). In both studies, precise irrigation applications saved water, yet growth was reduced by $10 \%$ or less. Warsaw et al. (2009a) reported that whenever plants in DWU treatments were larger than control plants, they received less water than those in the control. However, the majority of plants studied (20 of 24) were unaffected by irrigation treatment (Warsaw et al., 2009a). Similarly, in this study, while the DWU treatments received less water than the control, growth, as measured by several methods, was the same or greater for all DWU treatments than controls throughout the study. Warsaw et al. (2009b) posited that nutrient leaching in the control was a possible cause for three of their four species in DWU-based treatments being larger. Since control ir-

rigation rates in this study were generally above DWU, some of the nutrients supplied by the slow-release fertilizer may have been lost from the substrate due to higher leaching as well.

Table 4. Growth index increase $(\mathrm{cm})$ of four conifers subjected to four irrigation treatments between 23 June and 16 Oct. 2009 and 7 June and 31 Oct. 2010

\begin{tabular}{lllll}
\hline & \multicolumn{3}{c}{ Treatment } \\
\cline { 2 - 5 } Taxa & Control $^{\mathrm{z}}$ & $100 \mathrm{DWU}$ & $100-75 \mathrm{DWU}$ & $100-75-75 \mathrm{DWU}$ \\
\hline 2009 & & & \\
Chamaecyparis obtusa 'Filicoides' & $1.45 \mathrm{Bb}^{\mathrm{y}}$ & $5.22 \mathrm{ABa}$ & $4.48 \mathrm{ABab}$ & $7.69 \mathrm{Aa}$ \\
$\quad$ Chamaecyparis pisifera 'Sungold' & $1.70 \mathrm{Aab}$ & $1.89 \mathrm{Ab}$ & $2.37 \mathrm{Ab}$ & $1.39 \mathrm{Ac}$ \\
Thuja occidentalis 'Holmstrup' & $2.63 \mathrm{Aab}$ & $3.26 \mathrm{Aab}$ & $3.57 \mathrm{Ab}$ & $2.49 \mathrm{Ac}$ \\
Thuja plicata 'Zebrina' & $4.22 \mathrm{Aa}$ & $5.30 \mathrm{Aa}$ & $6.43 \mathrm{Aa}$ & $5.04 \mathrm{Ab}$ \\
2010 & & & & \\
C. obtusa 'Filicoides' & $7.50 \mathrm{Ba}$ & $12.71 \mathrm{Aa}$ & $9.50 \mathrm{ABa}$ & $9.32 \mathrm{ABa}$ \\
C. pisifera 'Sungold' & $4.78 \mathrm{Aa}$ & $4.96 \mathrm{Ac}$ & $5.04 \mathrm{Ab}$ & $5.09 \mathrm{Ac}$ \\
T. occidentalis 'Holmstrup' & $4.48 \mathrm{Aa}$ & $5.79 \mathrm{Abc}$ & $5.31 \mathrm{Ab}$ & $5.90 \mathrm{Abc}$ \\
T. plicata 'Zebrina' & $7.28 \mathrm{Aa}$ & $8.92 \mathrm{Ab}$ & $9.02 \mathrm{Aa}$ & $8.64 \mathrm{Aa}$ \\
\hline
\end{tabular}

${ }^{\mathrm{z}}$ Control $=19 \mathrm{~mm}$ per application ( $\mathrm{L}$ per container per day); $100 \mathrm{DWU}=100 \%$ daily water use (DWU) replacement each day; $100-75 \mathrm{DWU}=2$-d cycle alternating $100 \%$ and $75 \% \mathrm{DWU}$; and $100-75-75 \mathrm{DWU}=$ 3 -d cycle $100 \%$ DWU replacement the 1st day then $2 \mathrm{~d} 75 \%$ DWU replacement. Irrigation scheduling based on: 2009) highest DWU of the four taxa recorded on each day of sampling; 2010) highest DWU of the four taxa in each treatment replicate each day.

${ }^{y}$ Means separation performed with Tukey's test $(\alpha=0.05), \mathrm{n}=18$ (2009), and $\mathrm{n}=3$ (2010). Means followed by the same letters (capital letters in rows, lowercase letters in columns) are not different within respective years.

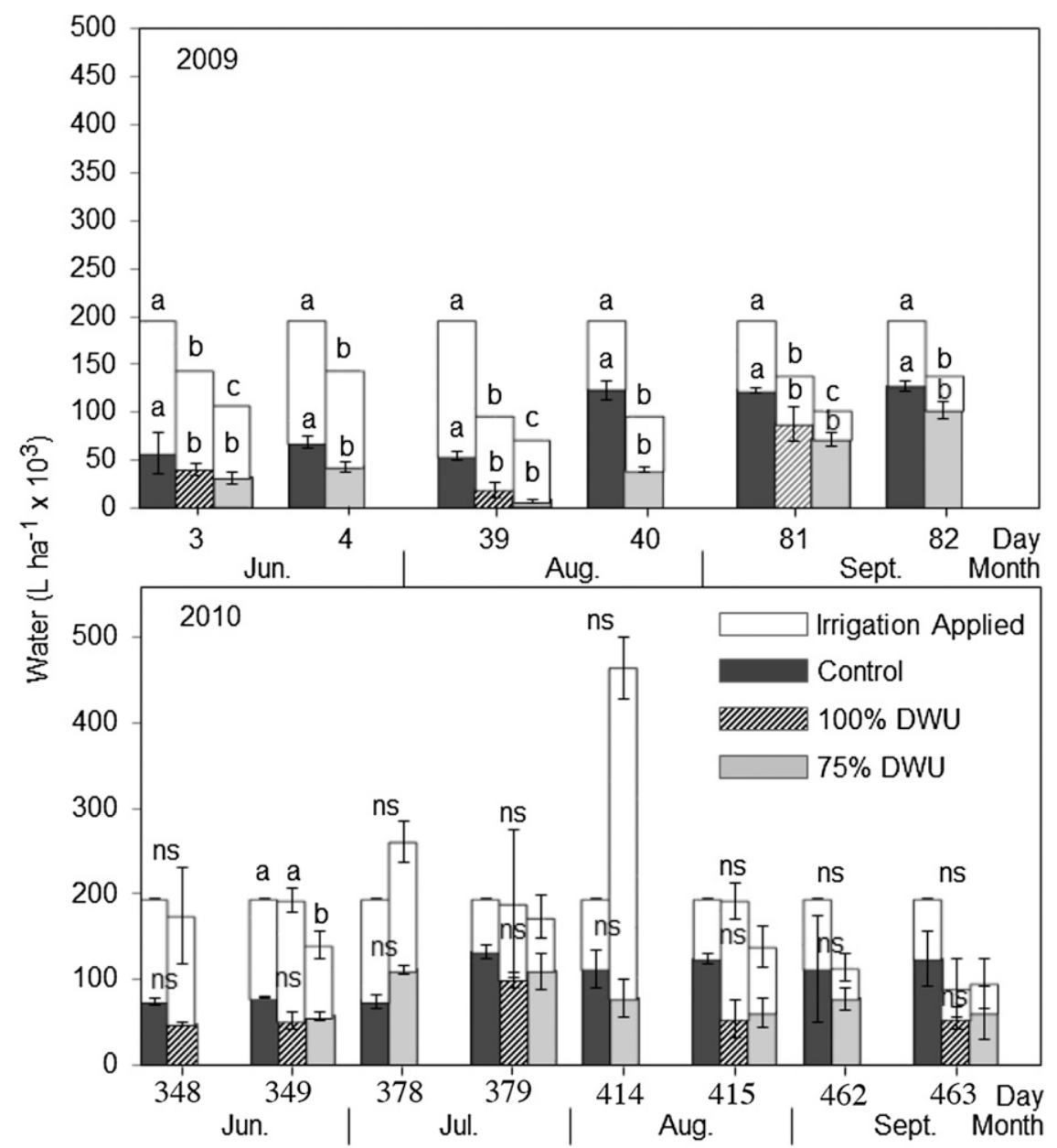

Fig. 5. Applied irrigation and recovered runoff from $3 \times 6 \mathrm{~m}$ production areas (projected to $\mathrm{L} \cdot \mathrm{ha}^{-1}$ ) from 25 June (Day 0) to 16 Oct. 2009 and 7 June (Day 348) to 31 Oct. 2010 (Day 494) for four conifers growing in 10.2-L containers. On days with two bars, all DWU treatments received irrigation at $100 \%$ DWU replacement. On days with three bars, 100-75 DWU and 100-75-75 DWU treatments were scheduled at $75 \%$ DWU replacement. Control treatment equivalent of $190 \times 10^{3} \mathrm{~L}^{2} \mathrm{ha}^{-1}$ applied daily. Means separation for each day performed using Tukey's test $(\alpha=0.05$, Ns $=$ not significant, $n=3)$. 
Runoff volume. Irrigation applied and runoff volumes from the DWU treatments were lower than the control on all measurement days in 2009 (Fig. 5). Since applied irrigation and $\theta$ in the deficit treatments were lower than $100 \mathrm{DWU}$ and control, runoff was lower due to less water being applied to nontarget areas and less leaching from containers. Similarly, runoff was lower for 100 DWU than control. Highest volumes of irrigation applied and runoff recovered occurred on Day 81 for the 75 DWU applications, Day 82 for the $100 \%$ applications, and Day 82 for the control. The lowest volumes applied and recovered for these rates occurred on Day 39. The 100 and 75 DWU irrigation volumes overall were $34 \%$ and $51 \%$ less than the control. Of the volume applied, 49\%, 46\%, and 39\% were recovered as runoff from the control, $100 \mathrm{DWU}$, and 75 DWU applications, respectively. Warsaw et al. (2009b) reported similar results with $60 \%, 37 \%$, and $32 \%$ runoff being recovered from their control, 100 DWU, and 75 DWU irrigation applications. Studies by Fare et al. (1994) and Karam and Niemiera (1994) also demonstrated that reduced irrigation volumes reduced leaching. Since irrigation application rates in 2010 were determined every day rather than only every $10-14 \mathrm{~d}$ as in 2009 , irrigation volumes in 2010 DWU treatments were only lower than the control on Day 349 and there were no differences in runoff volume due to treatment (Fig. 5).

Nitrates and phosphates. Concentrations of $\mathrm{NO}_{3}{ }^{-} \mathrm{N}$ in runoff tended to be low early and late during the measurement periods and peaked in the middle for both seasons (Fig. 6). In 2009, this peak occurred on Day 39 for the $100 \%$ and $75 \%$ DWU rate at 35.8 and $39.3 \mathrm{mg} \cdot \mathrm{L}^{-1}$, respectively, while the control peaked on both Days 39 and 40 at $17.2 \mathrm{mg} \cdot \mathrm{L}^{-1}$ (Fig. 6), nearly four times as high as the U.S. EPA limit of $10 \mathrm{mg} \cdot \mathrm{L}^{-1}$ for drinking water (Anonymous, 1986). Concentrations of $\mathrm{NO}_{3}^{-}-\mathrm{N}$ recovered in the $100 \%$ and $75 \%$ DWU basins were over twice as high as concentrations in the control basins on Day 39 because irrigation rates applied to the control were higher (Figs. 5 and 6).

In 2010, peak $\mathrm{NO}_{3}^{-}-\mathrm{N}$ concentrations occurred on Day 378 at $19.9 \mathrm{mg} \cdot \mathrm{L}^{-1}$ for the $100 \%$ irrigation applications and on Day 379

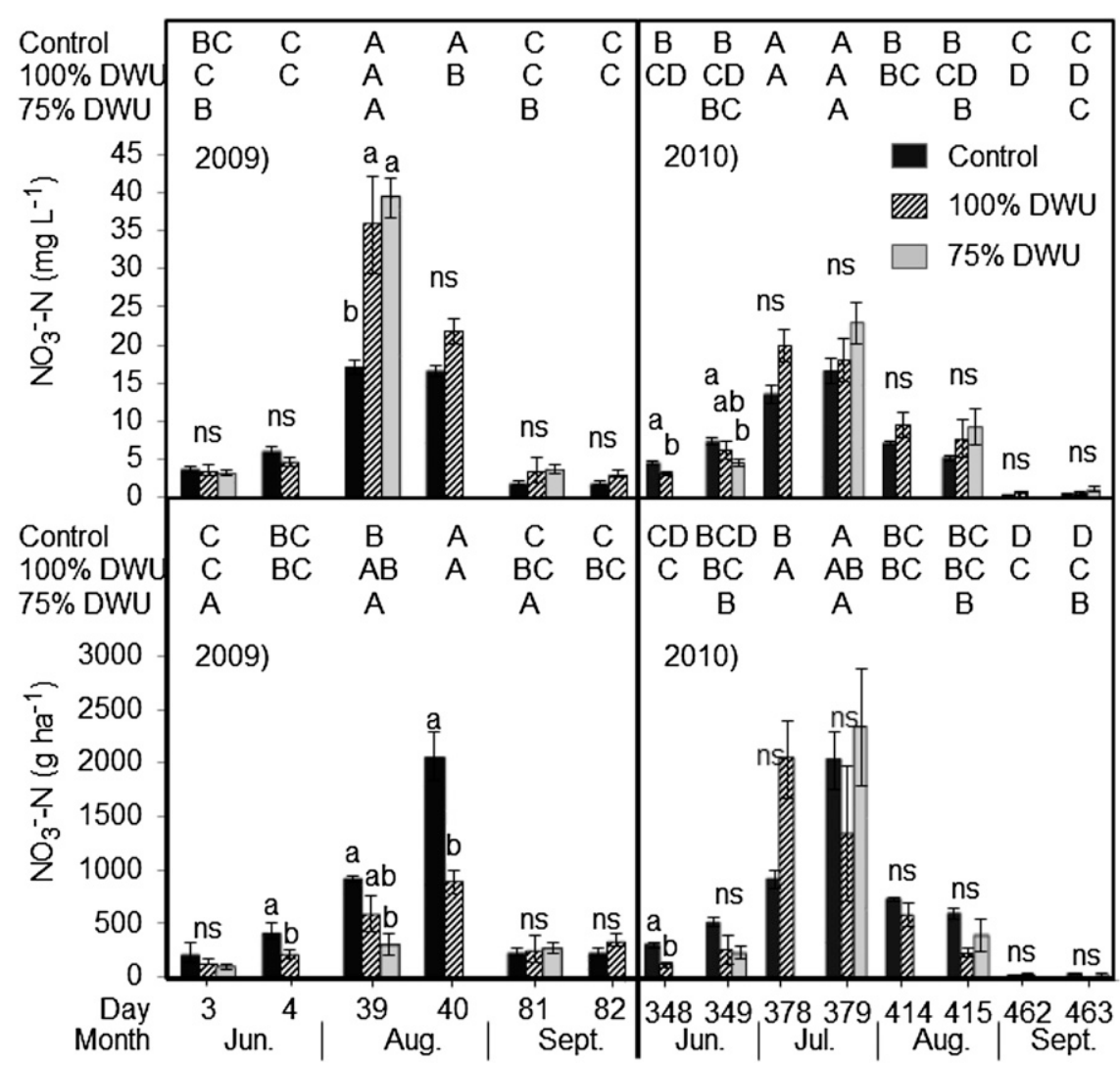

Fig. 6. $\mathrm{NO}_{3}{ }^{-} \mathrm{N}$ concentration in 2009 (A) and 2010 (B) and $\mathrm{NO}_{3}{ }^{-}-\mathrm{N}$ load in 2009 (C) and 2010 (D) for runoff collected from $3 \times 6 \mathrm{~m}$ production areas (projected to $\mathrm{g} \cdot \mathrm{ha}^{-1}$ ) from 25 June (Day 0) to 16 Oct 2009 and 7 June (Day 348) to 31 Oct. 2010 (Day 494) for four conifers growing in 10.2-L containers. Fertilizer was applied on 22 June 2009 and 6 June 2010. On days with two bars, irrigation was scheduled for all DWU treatments at $100 \%$ DWU replacement. On days with three bars, 100-75 and 100-75-75 DWU treatments were scheduled for 75\% DWU replacement. Control irrigation volume $=$ $190 \times 10^{3} \mathrm{~L} \cdot \mathrm{ha}^{-1}$ applied daily. Uppercase letters indicate means separation between measurement days within each treatment $(\alpha=0.05,2009$ control and 100\% DWU: $n=6 ; 75 \%$ DWU: $n=3,2010$ : control and $100 \%$ DWU: $n=8 ; 75 \%$ DWU: $n=4)$. Lowercase letters indicate means separation between treatments within each measurement day. Means separation performed using Tukey's test $(\alpha=0.05$, NS $=$ not significant, $\mathrm{n}=3$ ). for the $75 \%$ applications at $22.9 \mathrm{mg} \cdot \mathrm{L}^{-1}$ and control at $16.6 \mathrm{mg} \cdot \mathrm{L}^{-1}$ (Fig. 6), about twice the U.S. EPA limit (Anonymous, 1986). The lowest concentrations occurred on Days 462 and 463 (Fig. 6). On Day 348, concentration of $\mathrm{NO}_{3}{ }^{-} \mathrm{N}$ was greater in the control than for the $100 \%$ DWU and greater than the $75 \%$ DWU irrigation on Day 349 (Fig. 6). Differences in $\mathrm{NO}_{3}{ }^{-}-\mathrm{N}$ concentrations did not occur on any other days in 2010. In both seasons, peak runoff recovery was observed $\approx 30-40 \mathrm{~d}$ after fertilizer applications.

The runoff $\mathrm{NO}_{3}{ }^{-} \mathrm{N}$ load was greater for the control than 100 DWU on Days 4 and 40 in 2009 but only Day 348 in 2010 (Fig. 6). When all three irrigation treatments were applied on Day 39, $\mathrm{NO}_{3}{ }^{-} \mathrm{N}$ load from the control exceeded 75 DWU. Similar to the response seen in 2009, nutrient loading in 2010 peaked midseason on Day 378 (August) for 100 DWU and Day 379 for the other two treatments. Peak nutrient loading corresponded to peak season temperatures in August (Fig. 2). Birrenkott et al. (2005) found a similar release pattern for controlled-release fertilizer with daily $\mathrm{N}$ release peaking midseason, which they attributed to higher temperatures during that period.

Runoff $\mathrm{PO}_{4}{ }^{3-}$ - $\mathrm{P}$ concentrations also peaked shortly after nutrient applications were made. Peak $\mathrm{PO}_{4}{ }^{3-}-\mathrm{P}$ concentrations in 2009 occurred on Day 4 for the control at $3.4 \mathrm{mg} \cdot \mathrm{L}^{-1}$, while concentrations for the $100 \%$ and $75 \%$ DWU were generally higher during the first four collection days than the latter $2 \mathrm{~d}$ (Fig. 7). The only difference for $\mathrm{PO}_{4}{ }^{3-}-\mathrm{P}$ concentration between irrigation treatments observed in 2009 occurred on Day 82 where the 100 DWU was $270 \%$ higher than the control. In 2010, $\mathrm{PO}_{4}{ }^{3-}-\mathrm{P}$ concentration peaked on Days 348 and 349 for the control and Days 349 and 379 for the 75\% DWU (Fig. 7). Runoff $\mathrm{PO}_{4}{ }^{3-}-\mathrm{P}$ concentrations in the $100 \%$ DWU were greater on the first three sampling days than the last three sampling days. Similarly, control and 75\% DWU concentrations were lower late in the season compared with earlier. In 2010, the only difference in $\mathrm{PO}_{4}{ }^{3-}$-P concentration was when the control exceeded the $100 \%$ DWU on Day 348 (Fig. 7). Warsaw et al. (2009b) also reported occurrences of runoff nutrient concentrations recovered from their control being lower than $100 \%$ or $75 \%$ DWU irrigation application rates.

On Days 4 and 40, $\mathrm{PO}_{4}{ }^{3-}-\mathrm{P}$ loading of the $100 \%$ DWU application was $59 \%$ and $67 \%$ less than the control. On Day 39, loading in the $75 \%$ DWU was $81 \%$ lower than the control (Fig. 7). Peak $\mathrm{PO}_{4}{ }^{3-}-\mathrm{P}$ loading occurred on Day 4 for the control and $100 \%$ DWU (Fig. 7). Only one difference in $\mathrm{PO}_{4}{ }^{3-}-\mathrm{P}$ loading occurred in 2010 where the control exceeded the $100 \%$ DWU on Day 348 (Fig. 7). Although quantities of $\mathrm{PO}_{4}{ }^{3-}-\mathrm{P}$ recovered in the $100 \%$ DWU was $63 \%$ less than the control irrigation volumes did not differ. Highest $\mathrm{PO}_{4}{ }^{3-}$-P loading occurred on Day 348 for the control, Day 378 for the $100 \%$ DWU, and Day 379 for the 75\% DWU. Lowest $\mathrm{PO}_{4}{ }^{3-}$-P loading was observed during 


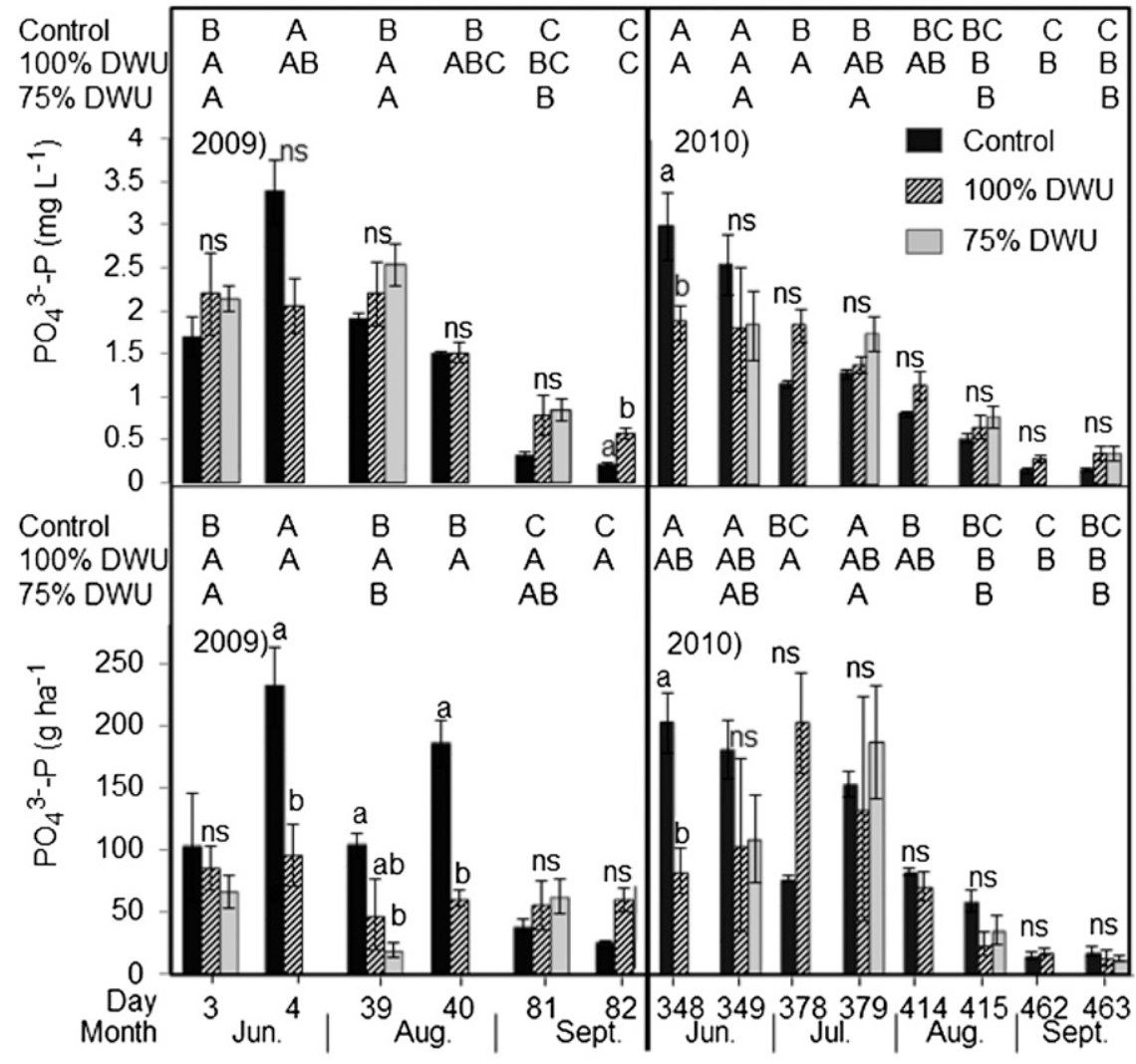

Fig. 7. $\mathrm{PO}_{4}{ }^{3-}-\mathrm{P}$ concentration in 2009 (A) and 2010 (B) and $\mathrm{PO}_{4}{ }^{3-}-\mathrm{P}$ load in 2009 (C) and 2010 (D) for runoff collected from $3 \times 6 \mathrm{~m}$ production areas (projected to $\mathrm{g} \cdot \mathrm{ha}^{-1}$ ) from 25 June (Day 0) to 16 Oct. 2009 and 7 June (Day 348) to 31 Oct. 2010 for four conifers growing in 10.2-L containers. Fertilizer was applied on 22 June 2009 and 6 June 2010. On days with two bars, irrigation was scheduled for all DWU treatments at $100 \%$ DWU replacement. On days with three bars, 100-75 and 100-75-75 DWU treatments were scheduled for $75 \%$ DWU replacement. Control irrigation volume $=190 \times 10^{3} \mathrm{~L} \cdot \mathrm{ha}^{-1}$ applied daily. Uppercase letters indicate means separation between measurement days within each treatment $(\alpha=0.05,2009$ control and 100\% DWU: $n=6 ; 75 \%$ DWU: $n=3,2010$ : control and 100\% DWU: $\mathrm{n}=8 ; 75 \%$ DWU: $\mathrm{n}=4)$. Lowercase letters indicate means separation between treatments within each measurement day. Means separation performed using Tukey's test $(\alpha=0.05$, NS $=$ not significant, $\mathrm{n}=3$ ).

the last collection period (Days 462-463) for all application rates (Fig. 7).

In contrast to nutrient concentration, loading in runoff tended to increase with increasing irrigation volume. Fewer differences in $\mathrm{NO}_{3}{ }^{-}-\mathrm{N}$ loading in 2010 compared with 2009 likely resulted from irrigation volumes of the DWU treatments and the control only differing on two of eight measurement days. The control and DWU irrigation rates differed on every measurement day in 2009 (Fig. 5). Several other studies have found decreased nutrient movement with reduced irrigation applications. Warsaw et al. (2009b) found that compared with their control, $\mathrm{NO}_{3}{ }^{-} \mathrm{N}$ loading in runoff was reduced, on average, $38 \%$ and $59 \%$ with their $100 \%$ and $75 \%$ DWU application rates. Likewise, $\mathrm{PO}_{4}{ }^{3-}-\mathrm{P}$ loading in their $100 \%$ and $75 \%$ DWU treatments were $46 \%$ and $74 \%$, respectively, lower than their control. Fare et al. (1994) showed that at an irrigation volume of $13 \mathrm{~mm}, 63 \%$ of $\mathrm{NO}_{3}^{-}-\mathrm{N}$ applied was recovered in runoff, whereas only $19 \%$ was recovered under 6-mm irrigation applications. Similarly, compared with their high LF treatment of 0.4-0.6, Tyler et al. (1996) reported that a low LF of $0.0-0.2$ reduced $\mathrm{NO}_{3}{ }^{-}-\mathrm{N}, \mathrm{NH}_{4}-\mathrm{N}$, and total $\mathrm{P}$ quantities recovered in runoff by $66 \%, 62 \%$, and $57 \%$, respectively.

\section{Conclusions}

Irrigation applications averaged over both years were reduced by $22 \%, 24 \%$, and $28 \%$, in the $100,100-75$, and $100-75$ 75 DWU treatments, respectively, compared with the control. Growth throughout the experiment for the DWU based treatments was the same or greater than the control. Also, the $100 \%$ and $75 \%$ DWU irrigation applications reduced runoff $\mathrm{NO}_{3}{ }^{-}-\mathrm{N}$ loading by $36 \%$ and $67 \%$ and $\mathrm{PO}_{4}{ }^{3-}-\mathrm{P}$ loading by $38 \%$ and $57 \%$ when averaged overall measurement days. Not only does this translate to less eutrophication potential, but it could also save growers money in the form of fewer nutrient inputs and potentially lower energy costs for the pumping and distribution of water. The classification of the four container-grown taxa by water use group adds to the body of work by Warsaw et al. (2009a, 2009b) and Burger et al.
(1987) to aid in grouping plants in nursery irrigation blocks according to $\mathrm{K}_{\mathrm{c}}$. Although both Warsaw et al. (2009b) and Karam and Niemiera (1994) showed that scheduling irrigation to replace $100 \%$ DWU (a LF of 0 ) in humid climates can be accomplished without electrical conductivity (EC) exceeding recommended levels (above 1.5 dS, Owen et al., 2011), EC should be frequently monitored and substrates leached whenever necessary.

The ability of the automated system to adapt to changes in DWU with daily resolution demonstrates great potential as a convenient and accurate scheduling tool. Grower-friendly systems are being developed that permit multiple sensor inputs, including soil moisture, EC, soil temperature, air temperature, relative humidity, precipitation, and photosynthetically active radiation, in a multilayer, self-configuring network capable of transmitting data wirelessly (Lea-Cox et al., 2011, 2013). Ultimately, such accessible and flexible automated systems in the hands of growers will help them make more informed production decisions (Lea-Cox et al., 2011, 2013), whereas DWU-based irrigation scheduling can serve as a promising solution in reducing runoff volume and the quantity of nutrients lost from production areas.

\section{Literature Cited}

Allen, R.G., L.S. Pereira, D. Raes, and M. Smith. 1998. Crop evapotranspiration: Guidelines for computing crop water requirements. Irrigation and Drainage Paper No. 56, FAO, Rome, Italy. Anonymous. 1986. Quality criteria for water. USEPA Rpt. 440/5-86-001. U.S. EPA Office of Water Regulation and Standards. U.S. Govt. Printing Office (PB87-226759), Washington, DC.

Anonymous. 2008. Total maximum daily load for phosphorus for Bear Lake Muskegon County. 29 Jan. 2012. <http://www.michigan.gov/documents/ deq/wb-swas-tmdl-bearlake_258228_7.pdf $>$.

Anonymous. 2011. Approved TMDL list. Michigan Department of Environmental Quality. 6 Feb. 2012. <http://www.michigan.gov/documents/deq/ wb-swas-tmdl-approvedlist_212987_7.pdf>.

Bayer, A., J. Ruter, and M. van Iersel. 2015. Automated irrigation control for improved growth and quality of Gardenia jasminoides 'Radicans' and ‘August Beauty'. HortScience 50:78-84.

Beeson, Jr., R.C., 2004. Modelling actual evapotranspiration of Ligustrum japonicum from rooted cuttings to commercially marketable plants in 12 liter black polyethylene containers. IV $^{\text {th }}$ ISHS on Irrigation of Horticultural Crops. Acta Hort. 664:71-77.

Beeson, Jr., R.C. M.A. Arnold, T.E. Bilderback, B. Bolusky, S. Chandler, H.M. Gramling, J.D Lea-Cox, J.R. Harris, P.J. Klinger, H.M. Mathers, J.M. Ruter, and T.H. Yeager. 2004. Strategic vision of container nursery irrigation in the next ten years. J. Environ. Hort. 22(2):113-115.

Belayneh, B.E., J.D. Lea-Cox, and E. Lichtenberg. 2013. Costs and benefits of implementing sensorcontrolled irrigation in a commercial pot-in-pot container nursery. HortTechnology 23:760-769.

Birrenkott, B.A., J.L. Craig, and G.R. McVey. 2005. A leach collection system to track the release of nitrogen from controlled-release fertilizers in container ornamentals. HortScience 40:1887-1891. 
Burger, D.W., J.S. Hartin, D.R. Hodel, T.A. Lukaszewski, S.A. Tjosvold, and S.A. Wagner. 1987. Water use in California's ornamental nurseries. Calif. Agr. 1987:7-8.

Chesapeake Bay Foundation. 2010. 2010 state of the bay. 3 July 2012. <http://www.cbf.org/ document.doc?id=596>.

Chappell, M., S.K. Dove, M.W. van Iersel, P.A. Thomas, and J. Ruter. 2013. Implementation of wireless sensor networks for irrigation control in three container nurseries. HortTechnology 23:747-753.

Cornejo, C., D.Z. Haman, and T.H. Yeager. 2005. Evaluation of soil moisture sensors, and their use to control irrigation systems for containers in the nursery industry. ASAE Meeting Paper No. 054056. ASAE, St. Joseph, MI.

EPA. 2011. FY2010 national report on implementing total maximum daily loads (TMDLs). Document \#EPA941-R-11-002. Office of Water, US Environmental Protection Agency, Washington, DC. 2 Nov. 2013. <http://water. epa.gov/lawsregs/lawsguidance/cwa/tmdl/results_ index.cfm $>$.

Fare, D.C., C.H. Gilliam, and G.J. Keever. 1992. Monitoring irrigation at container nurseries. HortTechnology 2:75-78.

Fare, D.C., C.H. Gilliam, G.J. Keever, and J.W. Olive. 1994. Cyclic irrigation reduces container nitrate-nitrogen concentration. HortScience 29:1514-1517.

Florida Department of Environmental Protection (FDEP). 2001. Total maximum daily load for total phosphorus, Lake Okeechobee, Florida. 2 Nov. 2013. <https://www.dep.state.fl.us/water/ tmdl/docs/tmdls/final/gp1/Lake_O_TMDL_ Final.pdf $>$.

Frank, K., D. Beegle, and J. Denning. 1998. Recommended phosphorus tests. In: J.R. Brown (ed.). Recommended chemical soil test procedures for the North Central region. North Central
Regional Publication No. 221 (revised). Missouri Agr. Expt. Stat. SB 1001. Columbia, MO.

Groves, K.M., S.L. Warren, and T.E. Bilderback. 1998. Irrigation volume, application, and controlledrelease fertilizers: I. Effect on plant growth and mineral nutrient content in containerized plant production. J. Environ. Hort. 16(3):176-181.

Karam, N.S. and A.X. Niemiera. 1994. Cyclic sprinkler irrigation and pre-irrigation substrate water content affect water and $\mathrm{N}$ leaching from containers. J. Environ. Hort. 12(4):198-202.

Kincaid, D.C. and D.F. Heerman. 1974. Scheduling irrigations using a programmable calculator. USDA-ARS-NC-12. US Govt. Printing Office, Washington, DC

Lea-Cox, J.D., D.S. Ross, and K.M. Teffeau. 2001. A water and nutrient management planning process for container nursery and greenhouse production systems in Maryland. J. Environ. Hort. 19(4):230-236.

Lea-Cox, J.D., F. Arguedas Rodriguez, A.G. Ristvey, D.S. Ross, and G. Kantor. 2011. Wireless sensor networks to precisely monitor substrate moisture and electrical conductivity dynamics in a cut-flower greenhouse operation. Proc. from the International Symposium on High Technology for Greenhouse Systems. Acta Hortic. 893, ISHS 2011.

Lea-Cox, J.D., W.L. Bauerle, M.W. van Iersel, G.F. Kantor, T.L. Bauerle, E. Lichtenberg, D.M. King, and L. Crawford. 2013. Advancing wireless sensor networks for irrigation management of ornamental crops: An overview. HortTechnology 23:717-724.

Michigan State University (MSU). Enviro-weather. 2011. 20 Jan. 2014. <http://enviroweather.msu. edu/homeMap.php $>$.

Nemali, K.S. and M.W. van Iersel. 2006. An automated system for controlling drought stress and irrigation in potted plants. Sci. Hort. 110:292-297.

Niu, G., D.S. Rodriguez, R. Cabrera, C. McKenney, and W. Mackay. 2006. Determining water use and crop coefficients of five woody landscape plants. J. Environ. Hort. 24(3):160-165.

O’Neill, M.P. and J.P. Dobrowolski. 2011. Water and agriculture in a changing climate. HortSci. 46:152-154.

Owen, J., J. Atland, A. Lebude, and H. Stoven. 2011. Monitoring soilless substrate solution $\mathrm{pH}$ and soluble salts in containerized ornamental nursery crops. Climate Friendly Nurseries Project, Oregon Association of Nurseries. 10 Sept. 2012. <http://www.climatefriendlynurseries. org/resources $>$.

Schuch, U.K. and D.W. Burger. 1997. Water use and crop coefficients of woody ornamentals in containers. J. Amer. Soc. Hort. Sci. 122: 727-734.

Sharma, J. and A. Bolques. 2007. Runoff water quality at container plant nurseries. Proc. of the Southern Nursery Association Research Conf. 52:138-142.

Tyler, H.H., S.L. Warren, and T.E. Bilderback. 1996. Reduced leaching fractions improve irrigation use efficiency and nutrient efficacy. J. Environ. Hort. 14(4):199-204.

Warsaw, A.L., R.T. Fernandez, B.M. Cregg, and J.A. Andresen. 2009a. Water conservation, growth, and water use efficiency of containergrown woody ornamentals irrigated based on daily water use. HortScience 44:13081318.

Warsaw, A.L., R.T. Fernandez, B.M. Cregg, and J.A. Andresen. 2009b. Container-grown ornamental plant growth and water runoff nutrient content and volume under four irrigation treatments. HortScience 44:1573-1580.

Warsaw, A.L., R.T. Fernandez, D.R. Kort, B.M. Cregg, B. Rowe, and C. Vandervoort. 2012. Remediation of metalaxyl, Trifluralin, and nitrate from nursery runoff using containergrown woody ornamentals and phytoremediation areas. Ecol. Eng. 47:254-263. 